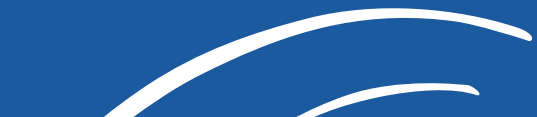 \\ AGUA Y TERRITORIO
}

\section{Agua, horticultura y urbanismo en una ciudad americana. Santiago de Chile en la época virreinal}

\author{
Water, Horticulture and Urban Planning in an American city. \\ Santiago de Chile in the Colonial Era
}

\author{
Martín Sánchez-Rodríguez \\ El Colegio de Michoacán. Zamora, México. mlobo@colmich.edu.mx
}

Resumen - El presente artículo tiene como objetivo principal estudiar los usos sociales del agua en Santiago de Chile a partir del uso de la cartografía antigua para así mostrar otros elementos presentes en el urbanismo americano y que van más allá de la planta en damero o la ubicación de edificios y espacios emblemáticos. Se trata de la red de acequias existentes en Santiago y en un número de poblaciones americanas aún no determinado, que marcaron su desarrollo urbano y fueron parte importante en la producción de alimentos a partir de la práctica de la horticultura.

La base de la presente contribución está compuesta por 24 documentos cartográficos impresos o dibujados entre 1713 y 1841, algunos de los cuales se reproducen aquí. Se trata de diez planos generales de Santiago y otros catorce planos parciales de la misma ciudad. Todos estos documentos fueron seleccionados al ofrecer información relativa a la ubicación y trayectoria de la red de canales y, en menor medida, a la práctica de la horticultura. Para reforzar ambos aspectos del trabajo, nos basaremos en las descripciones hechas por cronistas y viajeros de la época.

Abstract - This paper mainly aims to study the social uses of water in Santiago de Chile found in the ancient cartography in order to show other elements present in American urbanism that go beyond the checkerboard blueprint and the location of iconic buildings and spaces. We are referring to the network of existing irrigation ditches in Santiago, and in a countless number of American villages and towns, that marked its urban development and played an important role in the production of food through the practice of horticulture.

The sources used in this study consist of 24 cartographic documents printed or drawn between 1713 and 1841, some of which are reproduced here. They comprise 10 general surveys of Santiago and another 14 partial ones of the same city containing information on the location and trajectory of the irrigation ditch networks and to a lesser extent, the practice of horticulture. To strengthen both aspects of the work, we will rely on the descriptions given by travelers and chroniclers of the time.

\begin{abstract}
Palabras clave: urbanismo; traza urbana; Santiago de Chile; acequias; horticultura; cartografía colonial Keywords: urbanism; urban grid; Santiago de Chile; irrigationditches; horticulture; Colonial Cartogrphy
\end{abstract}

